\title{
Determination of Arsenic Species in P. calomelanos and $N$. biserrata
}

\author{
Luana B. Melendez, ${ }^{a}$ Emmanoel V. Silva-Filho, ${ }^{a}$ Norbert Miekeley, ${ }^{b}$ \\ Flavia de Almeida Vieira ${ }^{b}$ and Silvia M. Sella*,a \\ ${ }^{a}$ Instituto de Química, Universidade Federal Fluminense, Outeiro de São João Batista, s/n, Centro, \\ 24020-141 Niterói-RJ, Brazil \\ ${ }^{b}$ Departamento de Química, Pontifícia Universidade Católica do Rio de Janeiro (PUC-Rio), \\ Rua Marques de São Vicente, 225, Gávea, 22451-900 Rio de Janeiro-RJ, Brazil \\ O sítio industrial abandonado na Baía de Sepetiba (SE-Brasil) está entre os maiores passivos \\ ambientais contaminados com Zn no mundo e o As também se encontra em concentrações alarmantes. \\ A vegetação no local é escassa e das espécies que sobrevivem no local Pityrogramma calomelanos \\ e Nephrolepis biserrata são as mais abundantes. Concentrações de As de até $2271 \mathrm{mg} \mathrm{kg}^{-1}$ foram \\ detectadas na espécie Pityrogramma calomelanos, sendo que essa espécie foi mais eficiente que \\ $N$. Bisserata no acúmulo desse elemento.Utilizou-se cromatografia de exclusão por tamanho \\ (SEC) com detecção UV-Vis e espectrometria de massas com plasma indutivamente acoplado \\ (ICP-MS) em sistema "on line" para monitorar a distribuição de As na fração orgânica. As maiores \\ concentrações de As foram determinadas na fração extraída com TRIS-HCl, pH 7,4 (entre 60-100\% \\ da concentração total de As) mostrando uma evidente associação desse elemento com bioligantes, \\ entre eles, fitoquelatinas e glutationa.
}

The abandoned industrial site at the Sepetiba Bay (SE-Brazil) is one of the most heavily contaminated sites on the earth's surface concerned to $\mathrm{Zn}$, but also presents As in alarming concentrations. Vegetation on this site is scarce and under the surviving species Pityrogramma calomelanos and Nephrolepis biserrata are the most abundant ones. Total As concentrations up to $2271 \mathrm{mg} \mathrm{kg}^{-1}$ in $P$. calomelanos were determined, being this specie more efficient in arsenic accumulation than $N$. bisserata. The size exclusion chromatography (SEC) with UV-Vis detector coupled to inductively coupled plasma mass spectrometry (ICP-MS) was used to screen the distribution of As between different molar mass fractions. Highest concentration of As was found after extraction with TRIS-HCl, $\mathrm{pH} 7.4$ (about 60-100\% of total As) characterizing an association of this element with bioligands including phytochelatins and glutathione.

Keywords: terrestrial plants, phytochelatins, arsenic, speciation, SEC-UV-Vis-ICP-MS

\section{Introduction}

Sepetiba Bay is located $60 \mathrm{~km}$ from Rio de Janeiro city. Large population inflows and the construction of a harbour in the early 70's made the area further attractive for industrial development. In the past, the lack of environmental protection laws, society pressure and industrial social responsibilities had brought as a consequence a series of spots containing open-air waste piles resulting from the industrial activities. One such spot is located in an abandoned $\mathrm{Zn}$-producing in the Engenho Inlet inside Sepetiba Bay. In this area, Zn was extracted from calamine or willemite and arsenic trioxide

*e-mail: gqasela@vm.uff.br
$\left(\mathrm{As}_{2} \mathrm{O}_{3}\right)$ was used in a step of the purification process. An estimated amount of about 3 million tons of toxic waste has been accumulated in Sepetiba Bay since 1969, and concentrations of $\mathrm{Zn}, \mathrm{Cd}, \mathrm{Pb}$ and As in soil reach up $15 \%$, $0.1 \%, 0.5 \%$ and $250 \mathrm{mg} \mathrm{kg}^{-1}$, respectively. ${ }^{1,2}$

Vegetation in this site is scarce and under the surviving species Pityrogramma calomelanos and Nephrolepis biserrata are the most abundant. Studies regarding to the presence of arsenic species in plants are especially important considering their appearance in the food chain. The high level of arsenic in the studied area is a unique opportunity to investigate arsenic uptake by terrestrial plants naturally growing on a highly contaminated site.

It is well known from the literature that in mammals and marine organisms inorganic arsenic suffers 
biotransformation by two main processes: biomethylation or arsenic binding in organic molecules such as arsenobetaine and arsenosugars, which are considered non-toxic. ${ }^{3-5}$ However in plants arsenic detoxification seems to be related to phytochelatins that are peptides biosynthesised from glutathione GSH ( $\gamma$-Glu-Cys) $)_{n}$-Gly with $n$ varying from 2 to 11 , which are enzimatically sintetized by PC-sinterase. ${ }^{6-11}$

The most common techniques for separation and detection of biomolecules are a combination of separation techniques (such as liquid chromatography (LC), gas chromatography (GC), electrophoresis) with ICP-MS or graphite furnace atomic absorption spectrometry (GF AAS) for arsenic detection and UV-Vis for molecule screening. ${ }^{12}$

The aim of this work was to characterise arsenic species in P. calomelanos and N. bisserata growing in a highly contaminated area in order to provide some insight into the mechanisms involved in arsenic tolerances by plants species.

\section{Experimental}

\section{Equipments}

For speciation studies a chromatographic system composed by an isocratic bomb LC-200 (Perkin Elmer, CT, USA), a SEC column Superdex peptide 10/300 GL (Tricorn), an UV-Vis detector (Perkin Elmer) and an ICP-MS ELAN 5000A (Perkin-Elmer-Sciex) was used. Arsenic determination in extracts was performed by HG-ICP-MS using flow injection system (FIAS 200, Perkin Elmer) coupled to ICP-MS. Additionally, an ICP-MS model ELAN 6000 (Perkin Elmer-Sciex) was also used for total arsenic determination in plant samples.

\section{Reagents and standards}

Suprapur acids from Merck (Darmstadt, Germany) and water doubly distilled in quartz were used for the preparation of samples and standard solutions. All other reagents were of analytical reagent grade. A stock standard solution of As $\left(1000 \mathrm{mg} \mathrm{kg}^{-1}\right.$ in $\left.5 \% \mathrm{v} / \mathrm{v} \mathrm{HNO}_{3}\right)$ used for calibration in ICP-MS determinations was obtained from Merck. Fresh working standard solutions were prepared daily by dilution of stock solutions with water. The buffer solution used for extraction consisted of $10 \mathrm{mmol} \mathrm{L}^{-1}$ TRIS-HCl buffer (Sigma-Aldrich, Steinheim, Germany). The buffer $\mathrm{pH}$ was adjusted to 7.4 with an appropriate amount of $1 \mathrm{~mol} \mathrm{~L}^{-1}$ hydrochloric acid. Cystein (104 Da), metallothionein $(7 \mathrm{kDa})$, insulin $(6 \mathrm{kDa})$ and Dextran blue $(20 \mathrm{kDa})$ were used for column calibration.

\section{Sampling and sample preparation}

Plants were collected in a highly contaminated site located in Sepetiba Bay, SE-Brazil. This area has been widely studied mainly in relation to toxic elements contamination, identifying arsenic, ${ }^{13}$ chromium, cadmium and zinc as the main pollutants. ${ }^{14}$ Two plant species (Pityrogramma calomelanos and Nephrolepis biserrata), showing similar sizes, were collected in two sampling sites: along drainage channel (DC) and in a waste pile (WP). Then, they were packed into paper bags and transported to the laboratory. Immediately, samples were washed several times with deionised water (Milli-Q from Milipore, specific resistivity of $18 \mathrm{M} \Omega \mathrm{cm}$ ) and air-dried. Microscopic inspection of plant did not show any visible deposits of solid matter on the surface of them. For each group of 4 plants a composite sample was prepared. Each composite sample was mechanically ground using a stainless steel grinder, and then by careful homogenisation of the powder. These composite samples were stored in clean polyethylene tubes and kept frozen $\left(-4{ }^{\circ} \mathrm{C}\right)$ until analysis.

\section{Total arsenic determination}

Four replicates of $500 \mathrm{mg}$ of each composite plant samples were digested with $6 \mathrm{~mL}$ of 2-fold sub-boiled (Berghof, model Distill acid BSB-939-IR, Eningen, Germany) $\mathrm{HNO}_{3}$ (Merck, $65 \% \mathrm{~m} / \mathrm{m}$ ) and $3 \mathrm{~mL}$ of $\mathrm{H}_{2} \mathrm{O}_{2}$ (Merck Suprapur ${ }^{\circledR}$, $30 \% \mathrm{v} / \mathrm{v})$. For digestion, samples were placed in $50 \mathrm{~mL}$ graduated closed polypropylene tubes, which were placed into a heating block and kept at $90^{\circ} \mathrm{C}$ for $12 \mathrm{~h}$. After cooling, $3 \mathrm{~mL}$ of $\mathrm{H}_{2} \mathrm{O}_{2}$ (Merck Suprapur ${ }^{\circledR}, 30 \%$ v/v) were added and digestion continued during $3 \mathrm{~h}$. Sample extracts were then completed to $10 \mathrm{~mL}$ and centrifuged to separate small insoluble portion. This insoluble fraction was discharged and not considered for the results. Digests were diluted 10 times before the determination. The total arsenic determination was performed by ICP-MS, using ${ }^{103} \mathrm{Rh}$ as internal standard. A certified reference material (CRM) of tomato leaves (NIST, SRM 1573a, Gaithersburg, MD, USA) was used to check the accuracy of the analytical technique.

\section{Extraction procedures and efficiency}

Aliquots of $400 \mathrm{mg}(\mathrm{n}=3)$ of each composite plant sample were used for organic complexes extraction in three sequential steps, according to Połéc-Pawlak et al. ${ }^{15}$ The extraction procedure consisted basically of three steps: (i) (E1) - extraction with $10 \mathrm{mmol} \mathrm{L}^{-1}$ TRIS- $\mathrm{HCl}$ (pH 7.4) for aqueous complexes removal located at cytoplasm and vacuoles; (ii) (E2) - extraction with $1 \%(\mathrm{~m} / \mathrm{v})$ sodium dodecil 
sulfate (SDS) solution in $10 \mathrm{mmol} \mathrm{L}^{-1}$ TRIS-HCl (pH 7.4) for hydrophobic proteins removal and (iii) (E3) - extraction with $10 \mathrm{mmol} \mathrm{L}^{-1}$ ammonium acetate solution ( $\mathrm{pH}$ 4.6) for removal of small organic acids with low molecular mass. The extraction procedures were performed with $10 \mathrm{~mL}$ of extracting solution under agitation during $1 \mathrm{~h}$ with shaker, followed by centrifugation during $40 \mathrm{~min}(12000 \mathrm{rpm})$ at $5{ }^{\circ} \mathrm{C}$ in the same vessel.

In order to investigate the extraction efficiency, an aliquot of the extract obtained was digested as previously described. The determination of total arsenic concentration in those extracts was performed by hydride generation, ICP-MS (HG-ICP-MS). The extracts were diluted 100 times before the determination.

\section{Determination of inorganic arsenic species}

In order to obtain complementary information about As chemical forms present in the plant extracts, arsenic concentration was determined by HG, using FIAS 200 system with $\mathrm{NaBH}_{4}$ solution $(0.4 \% \mathrm{~m} / \mathrm{v}$, Merck) coupled to ICP-MS. Hydride generation allows elimination of most part of the sample matrix and because of that, the possible spectral polyatomic interference caused by the presence of chloride in the samples $\left({ }^{40} \mathrm{Ar}^{35} \mathrm{Cl}^{+}\right.$interferes on $\left.{ }^{75} \mathrm{As}^{+}\right)$is also avoided.

The procedure used for arsenic determination in extracts was similar to described by Stroh et al. ${ }^{16}$ Firstly, the As(III) was determined by direct injection of the original extracts in the HG-ICP-MS system. A second aliquot of the original extract was used to determine total inorganic As concentration $(\mathrm{III}+\mathrm{V})$ by pre reduction of $\mathrm{As}(\mathrm{V})$ to $\mathrm{As}(\mathrm{III})$ with $1 \mathrm{~mL}$ of $\mathrm{KI}(5 \% \mathrm{~m} / \mathrm{v}$, Merck) solution plus ascorbic acid $(5 \% \mathrm{~m} / \mathrm{v}$, Sigma-Aldrich) and $3 \mathrm{~mL}$ of concentrated $\mathrm{HCl}$ (Merck, $37 \% \mathrm{~m} / \mathrm{m}$ ), allowing this mixture to stand during $15 \mathrm{~min}$ before the HG-ICP-MS analysis. The concentration of $\mathrm{As}(\mathrm{V})$ was obtained by the difference between total inorganic arsenic and As(III) concentration. The original extract was used to determine total arsenic concentration (As(III) $+\mathrm{As}(\mathrm{V})+$ As organic), as follows: $(i)$ arsenic oxidation in closed polypropylene tubes with concentrated sub-boiled $\mathrm{HNO}_{3}$ placed in a digestion block at $80{ }^{\circ} \mathrm{C}$ overnight; evaporation of $\mathrm{HNO}_{3}$ in excess; (ii) pre reduction of $\mathrm{As}(\mathrm{V})$ to As(III) and arsenic determination by HG-ICP-MS. Comparing the results obtained after complete oxidation of the extracts with $\mathrm{HNO}_{3}$ show information about the arsenic fraction associated to organic compounds (proteins, peptides, etc.).

\section{Organoarsenicals characterization}

For organoarsenicals characterization, the extracts obtained were immediately submitted to chromatographic analysis using SEC-UV-Vis-ICP-MS. For connection of UV-Vis detector output to ICP-MS a PEEK ${ }^{\circledR}$ tube was used. A Superdex peptide 10/300 GL column, UV-Vis detector for macromolecules monitoring and ICP-MS detector for ${ }^{75} \mathrm{As}^{+}$ monitoring were used. The elution times of cystein (104 Da), metallothionein $(7 \mathrm{kDa})$, insulin $(6 \mathrm{kDa})$ and Dextran blue $(20 \mathrm{kDa})$ were used to estimate the molecular mass. The analytical curve was plotted by injection of solutions containing adequate arsenic concentrations, prepared in the same medium used to extract the analyte from sample. This medium was also used as blank solution to compensate possible non-spectral interferences caused by saline matrix. The accuracy and repeatability of the results obtained were evaluated by analysis of a certified reference material (CASS4, seawater from National Research Council, Ottawa, ON, Canada) in each set of samples.

\section{Results and Discussion}

For evaluation of method accuracy, including samples digestion and arsenic determination by ICP-MS, certified reference material (SRM 1573a NIST) was analysed. Acceptable agreement was obtained $(114 \%, n=4)$ with similar repeatability to that recommended by NIST. Accuracy verification of HG-ICP-MS method was made by analysis of a seawater certified reference material (NRCC CASS-4) with good agreement $(105 \%, \mathrm{n}=5)$ and RSD about $14 \%$ for $1 \mu \mathrm{g} \mathrm{L}^{-1}$ solution. The limit of detection (LOD) was calculated by the ratio of three times the standard deviation of the blank $(n=10)$ and the slope of calibration curve. The limit of quantification (LOQ) was obtained by 3.3 times the LOD. The LOD and LOQ were 0.010 and $0.033 \mu \mathrm{g} \mathrm{kg}^{-1}$, respectively.

\section{Determination of total arsenic concentration}

Table 1 shows total arsenic concentration in plant species in both sampling points. It can be seen that arsenic concentrations are higher in P. calomelanos when compared to $N$. biserrata, regardless of the sample location.

P. calomelanos belongs to the same order (Pteridales) of Pteris vitatta, which is worldly recognised as specie that hipperaccumulates arsenic. The potential of this plant for phytoremediation of soil contaminated with arsenic has already been reported. ${ }^{17}$ The lower and similar arsenic concentrations in N. Biserrata observed in both sampling points (Table 1) suggests that some specie did not appear reflecting the arsenic contamination of those sites, as already observed. ${ }^{18}$

Although the number of samples was small, $P$. calomelanos showed large difference in arsenic 
Table 1. Total As concentration $(n=4)$ in sample plants and in each extract $(n=3)$ and extraction efficiency

\begin{tabular}{lccccc}
\hline Sample & Total As $/\left(\mathrm{mg} \mathrm{kg}^{-1}\right)$ & $\mathrm{E} 1 /\left(\mathrm{mg} \mathrm{kg}^{-1}\right)$ & $\mathrm{E} 2 /\left(\mathrm{mg} \mathrm{kg}^{-1}\right)$ & $\mathrm{E} 3 /\left(\mathrm{mg} \mathrm{kg}^{-1}\right)$ & Extraction efficiency / $\%)$ \\
\hline P. calomelanos $(\mathrm{DC})$ & $2271.0 \pm 47.0$ & $854.0 \pm 24.0$ & $278.0 \pm 12.0$ & $266.0 \pm 21.0$ & 60 \\
P. calomelanos (WP) & $510.0 \pm 32.0$ & $202.0 \pm 9.8$ & $78.9 \pm 0.8$ & $35.8 \pm 1.3$ & 60 \\
N. biserrata (DC) & $26.4 \pm 5.8$ & $7.6 \pm 0.3$ & $1.95 \pm 0.20$ & $1.2 \pm 0.2$ & 40 \\
N. biserrata (WP) & $36.7 \pm 2.7$ & $23.7 \pm 0.6$ & $13.2 \pm 0.6$ & $5.4 \pm 0.3$ & 115 \\
\hline
\end{tabular}

concentration between the drainage channel (DC) and the waste pile (WP) sampling points. Considering that the samples were collect at the same polluted sites, these variations may reflect differences in arsenic bioavailability between sampling location. According to Bech et al. ${ }^{19}$ in soils with high total arsenic concentration, the available arsenic fraction seems to be strongly influenced by soil texture and $\mathrm{pH}$. Moreover, differences in mineral content, especially Fe and Mn content in sampling locations may also interfere in arsenic bioavailability. ${ }^{17}$

Table 1 also shows mean $(n=3)$ of total arsenic concentration in each extract of the plants. Usually, extraction of arsenic species from plants is carried out with water/metanol mixtures ${ }^{16}$ but the extraction efficiency is low. The results obtained show that the main portion of total arsenic is extracted with $10 \mathrm{mmol} \mathrm{L}^{-1}$ TRIS-HCl ( $\mathrm{pH} \mathrm{7.4,}$ E1). When compared to the total arsenic concentration in the plant species it can be seen that approximately $60 \%$ of As in P. calomelanos is extractable, regardless arsenic concentration. These results are in agreement with data recently reported ${ }^{20}$ in a study of arsenic speciation analysis using sequential extraction (water/SDS).

However, it is important to notice that for $N$. biserrata arsenic extraction efficiency is different (40\% and 115\% for DC and WP, respectively) depending on the sample location. Considering that this specie shows lower arsenic tolerance compared to P. calomelanos, this is probably related to differences in arsenic species distribution in the environment. The higher anaerobic conditions in the drainage channel (DC) sampling point compared to waste pile (WP) one probably favours As(III) presence. ${ }^{21}$

\section{Arsenic speciation}

Based on the previous results we investigated which arsenic species were present in sample extracts. Table 2 shows the results obtained only from extract 1 (E1) due to its higher arsenic extraction efficiency.

The distribution of arsenic species shows that inorganic arsenic is present in all samples, with $\mathrm{As}(\mathrm{V})$ being the predominant specie when compared to As(III). The only exception is for $N$. Biserrata in the drainage channel (DC) where $\mathrm{As}(\mathrm{III})$ concentration is approximately twice higher than $\mathrm{As}(\mathrm{V})$.

Data from literature shows that, due to its similarity to phosphate, arsenate can be taken up by plants through phosphate transporters on the plasma membrane of root epidermal cells. ${ }^{22-25}$ Once inside the plant $\mathrm{As}(\mathrm{V})$ is reduced to $\mathrm{As}(\mathrm{III})$ and subsequently reacts with $\mathrm{SH}$-groups. ${ }^{26} \mathrm{So}$, it seems that the different behaviour presented by $N$. biserrata in both sampling locations suggests that this specie has more efficient control mechanisms of arsenite directly uptaken by the roots. The highest As(III) concentration in DC is probably associated to $\mathrm{As}(\mathrm{V})$ reduction inside the plant.

In general, partial mass balance indicates that As present in these plants (Table 2) is mainly associated to organic fraction, varying from 62 to $88 \%$ of total As mass present in extract 1 (E1).

In order to characterize whose organoarsenicals species were predominantly present, all plant extracts (E1, E2 and E3) were analysed by SEC-UV-Vis-ICP-MS. In general, the UV-Vis chromatograms for $P$. calomelanos and $N$. biserrata showed peaks with similar retention times regardless sample location.

The SEC-UV-Vis and the ICP-MS chromatograms (Figures 1 and 2) reveal that Pityrogramma calomelanos specie presents four peptides peaks associated to As. The retention times obtained by these peaks were used to identify molecular mass range of those peptides and the results are shown in Table 3. Peak 1 present an elution volume too close to the exclusion limit which make it

Table 2. As speciation by HG-ICP-MS in the extract 1 (TRIS-HCl 10 mmol L-1, $\mathrm{pH}$ 7.4) from all sample plants (mg $\mathrm{kg}^{-1}$ )

\begin{tabular}{lccccc}
\hline Extract 1 (E1) & As-total & As $(\mathrm{III})$ & As(III) + As(V) & As(V) & As-organic \\
\hline P. calomelanos (DC) & 854.0 & 42.6 & 150.0 & 707.0 & 704.0 \\
P. calomelanos (WP) & 202.0 & 21.4 & 0.0 & 53.6 & 127.0 \\
N. biserrata (DC) & 7.6 & 0.8 & 0.9 & 0.5 & 6.7 \\
N. biserrata (WP) & 23.7 & 1.1 & 6.4 & 5.4 & 17.3 \\
\hline
\end{tabular}


difficult to characterize. Peak 2 corresponds to metallic complexes with ligands of molecular mass ranging from 529 to $567 \mathrm{Da}$, characteristics of phytochelatins, probably $\mathrm{PC}_{2}\left((\gamma-\text { Glu-Cys })_{\mathrm{n}}-\mathrm{Gly}, \mathrm{n}=2, \mathrm{MM}=539 \mathrm{Da}\right)$.
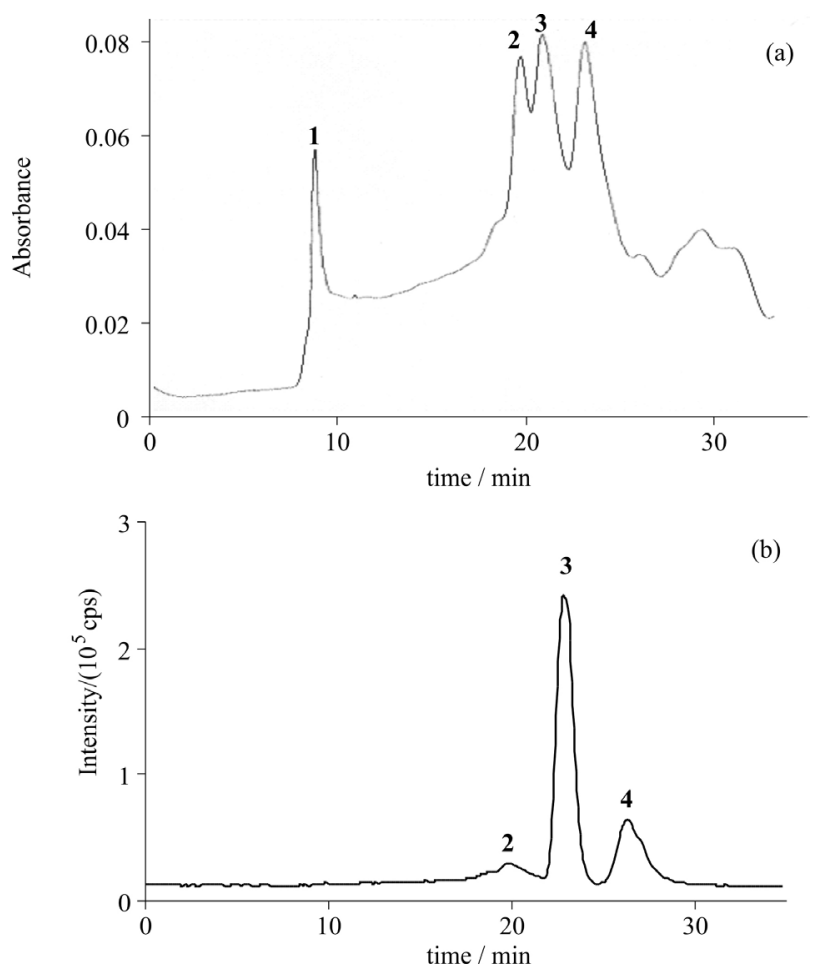

Figure 1. Chromatograms obtained by SEC-UV-Vis-ICP-MS (Superdex peptide column) for extract 1 (E1) of Pityrogramma calomelanos specie. (a) UV-Vis detector monitoring peptides; (b) ICP-MS detector monitoring arsenic.

Arsenic complexes in Pteris vittata bound to $\mathrm{PC}_{2}$ have already been identified. ${ }^{27}$ Other authors studying cells suspensions of $R$. serpentina showed that in the presence of arsenite/arsenate predominates $\mathrm{PC}_{2}$, while $\mathrm{PC}_{3}$ was predominated in presence of cadmium. ${ }^{6}$ Peak 3 corresponds to metallic complexes with ligands of molar mass between 342 and $363 \mathrm{Da}$, probably glutatione (GSH), a tri-peptide containing glutamic acid, cystein and glycin. On the other
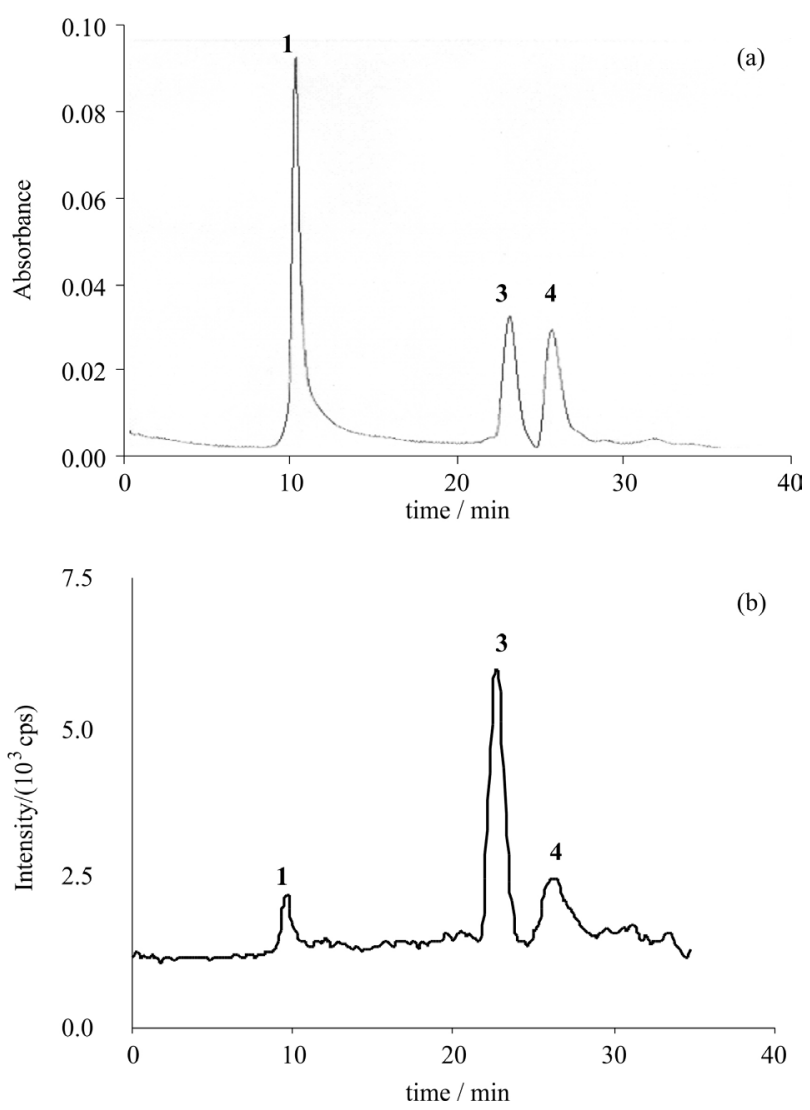

Figure 2. Chromatograms obtained by SEC-UV-Vis-ICP-MS (Superdex peptide column) for extract 3 (E3) of Pityrogramma calomelanos specie. (a) UV-Vis detector monitoring peptides; (b) ICP-MS detector monitoring arsenic.

hand, metallic complexes of molecular mass below $300 \mathrm{Da}$ (peak 4) may be a result of proteins degradation. According to Poléc-Pawlak et al.,$^{15}$ in a study of Cd speciation in Arabidopsis thaliana, this peak may correspond to metallic complexes with cystein.

The SEC-UV-Vis and the ICP-MS chromatograms (Figure 3) reveal that Nepholepis biserrata specie presents two proteins peaks associated to As. The retention times obtained by these peaks were used to identify those proteins (Table 3). Peak 3 corresponds to As associated to GSH and

Table 3. Retention times (average and standard deviations, $\mathrm{n}=6$ ); elution volumes; constant distribution (Kav) and molar mass range of the proteins from Pityrogramma calomelanos and Nephrolepis bisserata obtained using SEC-UV-Vis (a Superdex peptide 10/300 GL column was used)

\begin{tabular}{lcccc}
\hline Peak & Retention time / $\mathrm{min}$ & Elution volume / $\mathrm{mL}$ & Kav & Molecular Mass range / Da \\
\hline 2 & $20.3 \pm 0.1$ & Pytirogramma calomelanos & $529.0-567.0$ \\
3 & $21.6 \pm 0.1$ & $16.2-16.4$ & $0.525-0.535$ & $342.0-363.0$ \\
4 & $24.8 \pm 0.6$ & $17.2-17.3$ & $0.586-0.590$ & $89.0-140.0$ \\
\hline 3 & & $19.3-20.3$ & $0.716-0.778$ & $327.0-354.0$ \\
4 & $21.7 \pm 0.1$ & Nephrolepis biserrata & $70.1-79.2$ \\
\hline
\end{tabular}


Table 4. Average As concentration $\left(\mathrm{mg} \mathrm{kg}^{-1}, \mathrm{n}=3\right.$ ) associated with protein peaks from Pityrogramma calomelanos and Nephrolepis bisserata obtained using SEC-UV-Vis-ICP-MS (a Superdex peptide 10/300 GL column was used)

\begin{tabular}{lcccccc}
\hline Sample & Peak 1 & Peak 2 & Peak 3 & Peak 4 & Total As & Column recovery / (\%) \\
\hline P. calomelanos (DC) & 10.21 & 28.90 & 492.9 & 154.5 & 1398.0 & 49 \\
N. biserrata (DC) & - & - & 4.6 & 2.5 & 10.8 & 66 \\
P. calomelanos (WP) & 2.58 & 15.34 & 84.6 & 27.0 & 316.7 & 40 \\
N. biserrata (WP) & - & - & 16.0 & 10.1 & 42.3 & 64 \\
\hline
\end{tabular}
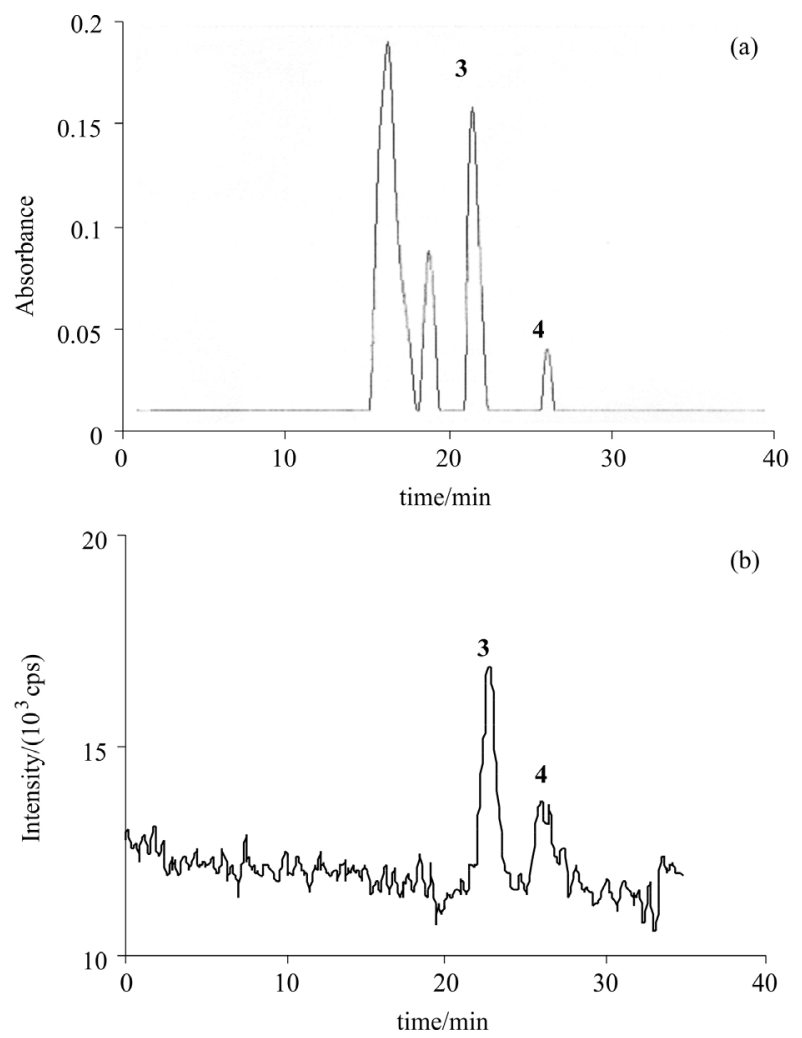

Figure 3. Chromatograms obtained by SEC-UV-Vis-ICP-MS (Superdex peptide column) for extract 1 (E1) of $N$. biserrata specie. (a) UV-Vis detector monitoring peptides; (b) ICP-MS detector monitoring arsenic.

peak 4 corresponds to As complexes with bioligands of molecular mass below $300 \mathrm{Da}$, probably cystein. ${ }^{15}$

\section{As distribution among plant species}

Table 4 shows arsenic concentration in each fraction obtained after separation in Superdex peptide column compared to arsenic total concentration presented in the original extract. These results show that the sum of As mass in extract 1 (E1) from $P$. calomelanos in both sampling locations corresponds to approximately $45 \%$ of total As present in this extract. On the other hand, for $N$. biserrata this percentage was higher (about 65\%). It is uncertain the reason for this incomplete chromatographic recovery. However we can speculate that the lower arsenic recoveries obtained for $P$. calomelanos specie are possibly related to its higher As mass present and perhaps, a fraction of this element may be retained in the column. On the other hand, arsenic peaks quantification in the $N$. biserrata species may be a difficult task, considering that their intensity is close to the baseline and peaks 1 and 2 were not observed.

\section{Conclusions}

The behaviour of $N$. Biserrata suggests that this specie is physiologically tolerant to As due to its lower total As concentration compared to $P$. calomelanos and relatively higher content of As bound to organic fraction. This may suggest that this specie controls arsenic uptake. Moreover, once inside the plant inorganic arsenic is reduced by a detoxification mechanism that involves proteins and/or peptides. Whether or not phytochelatins play an important role in the arsenic detoxification mechanisms of plants is still a matter of debate, but the results obtained in this study confirm data reported in the literature which indicate that PCs are induced in the presence of arsenic.

\section{Acknowledgments}

The authors would like to thank Alvaro J. Pereira for performing the ICP-MS measurements and INCTTMCOcean 573-601/2008-9 by financial support.

\section{References}

1. Molisani, M. M.; Marins R. V.; Machado, W.; Paraquetti, H. H. M.; Bidone, E. D.; Lacerda, L. D.; Reg. Environ. Change 2004, 4, 17.

2. Lacerda, L. D.; Molisani, M. M.; Mar. Pollut. Bull. 2006, 52, 969.

3. Kaise, T.; Fukui, S.; Appl. Organomet. Chem. 1992, 6, 155.

4. Li, W.; Wei, C.; Zhang, C.; Van Hulle, M.; Cornelis, R.; Zhang, X.; Food Chem. Toxicol. 2003, 41, 1103.

5. Cui, X.; Kobayashi, Y.; Hayakawa, T.; Hirano, S.; Toxicol. Sci. 2004, 82, 478.

6. Schmöger, M. E. V.; Oven, M.; Grill, E.; Plant Physiol. 2000, 122, 793. 
7. Hartley-Whitaker, J.; Ainsworth, G.; Vooijs, R.; Ten-Bookum, W.; Schat, H.; Meharg, A. A.; Plant Physiol. 2001, 126, 299.

8. Hartley-Whitaker, J.; Ainsworth, G.; Woods, C.; Meharg, A. A.; New Phytol. 2002, 155, 219.

9. Schat, H.; Llugany, M.; Vooijs, R.; Hatley-Whitaker, J. P. M; J. Exp. Bot. 2002, 53, 2381.

10. Montes-Bayòn, M.; Meija, J.; LeDuc, D. L.; Terry, N.; Caruso, J. A.; Sanz-Medel, A.; J. Anal. At. Spectrom. 2004, 19, 153.

11. Park, S. G.; Butcher, D. J.; Microchem. J. 2010, 95, 57.

12. Schaumlöffel, D.; Lobinski, R.; Int. J. Mass Spectrom. 2005, 242, 217.

13. Magalhães, V. F.; Pfeiffer, W.C.; J. Geochem. Explor. 1995, 52, 175.

14. Carvalho, C. E. V.; Lacerda, L. D.; Gomes, M. P.; Water, Air, Soil Pollut. 1991, 57, 645.

15. Połéc-Pawlak, K.; Ruzik, R.; Abramski, K.; Ciurzynska, M.; Gawronska, H.; Anal. Chim. Acta 2005, 540, 61.

16. Stroh, A.; Denoyer, E.; Lu, Q.; Völlkopf, U.; PerkinElmer-Sciex Appl. Report No. FAR-1; PerkinElmer: Norwalk, 1993.

17. Visoottiviseth, P.; Francesconi, K.; Sridokchan, W.; Environ. Pollut. 2002, 118, 453.

18. Ruiz-Chancho, M. J.; López-Sánchez, J. F.; Schmeisser, E.; Goessler, W.; Francesconi, K. A.; Rubio, R.; Chemosphere 2008, 71, 1522 .
19. Bech, C.; Poschenrieder, M.; Llugany, J.; Barcelo, P.; Toloias, J.; Sci. Total. Environ. 1997, 203, 83.

20. Jedynak, L.; Kowalska, J.; Harasimowicz, J.; Golimowski, J.; Sci. Total Environ. 2009, 407, 945.

21. Sadiq, M.; Water, Air, Soil Pollut. 1997, 93, 117.

22. Ulrich-Eberius C. I.; Sanz A.; Novacky A. J.; J. Exp. Bot. 1989, 40, 119.

23. Reina, S. V.; Esteban, E.; Goldsbrough, P.; Physiol. Plant. 2005, $12,441$.

24. Vetterlein, D.; Wesenberg, D.; Nathan, P.; Braütigam, A.; Schierhorn, A.; Mattusch, J.; Jahn, R.; Environ. Pollut. 2009, 157, 3016.

25. Srivastava, M.; Santos, J.; Srivastava, P.; Ma, L. Q.; Bioresour. Technol. 2010, 101, 2691.

26. Milucz, V. G.; Tatár, E.; Virág, I.; Cseh, E.; Fodor, F.; Záray, G.; Anal. Bioanal. Chem. 2005, 383, 461.

27. Zhang, W.; Cay, I.; Downum, K. R.; Ma, L. Q.; Environ. Pollut. 2004, 131, 337.

Submitted: January 18, 2011 Published online: August 18, 2011 